\title{
Førtidspension fra kompensationstanke til udviklingsfokus
}

\author{
Finn Amby, Sisse Schaldemose \& Anders Bøggild Christensen
}

Udviklingen på førtidspensionsområdet er velegnet til at belyse forandringer i social og arbejdsmarkedspolitikken. Artiklen belyser for det første, hvordan forandringer i tildelings- og udmålingsbestemmelser fra reformen i 1984 til de to seneste reformer i 2003 og 2013 ændrer ved balancen mellem socialpolitiske og arbejdsmarkedspolitiske hensyn. For det andet belyser artiklen hvilke ideer og tankegange, der er indlejret i de gradvise beslutninger om forandring af førtidspensionsområdet. En samlet tolkning er, at førtidspensionsområdet er gået fra et klassisk socialpolitisk område til at være en del af beskæftigelsespolitikken.

Nøgleord: Førtidspension, pensionsreformer, beskæftigelsespolitik, arbejdsmarkedspolitik, socialpolitik, arbejdsevne

\section{Indledning}

Førtidspension har over tiden undergået store forandringer fra indførelsen i 1921 til den seneste reform blev implementeret i 2013. Målgruppen for førtidspension, kriterierne for at få en bevilling samt det økonomiske forsørgelsesniveau er løbende forandret. I denne artikel tages især afsæt i udviklingen fra førtidspensionsreformen i 1984 til reformerne i 2003 og 2013.

Aktuelt er der store diskussioner om antallet af førtidspensionister. Kriterierne for at få tilkendt førtidspension er en tydelig markør for grænsen mellem det arbejdsbaserede og det behovsbaserede fordelingssystem (Stone, 1985). Denne grænse har flyttet sig markant gennem de seneste årtier med et skifte fra en socialpolitisk kompensations- og forsørgelsestænkning til en beskæftigelsespolitisk tænkning om at udnytte arbejdsevnen. Udviklingen på førtidspensionsområdet er derfor også velegnet i forhold til temaet om den forsvundne social- og arbejdsmarkedspolitik. Artiklen belyser to aspekter i relation hertil.

For det første er formålet $i$ et medborgerskabsperspektiv at belyse forandringer af førtidspension med fokus på adgang til forsørgelse og muligheder for deltagelse. Den historiske fremstilling har fokus på forandringer i hvilke målgrupper, der har adgang til førtidspension og relaterede systemer samt reglerne for udmåling af forsørgelsesydelser. Der er flere kilder til at understøtte 
en sådan fremstilling ${ }^{1}$, men målet er her at bidrage med en samlet fremstilling af udviklingens centrale aspekter.

Tesen er, at de ændrede tildelingskriterier, der formelt set aktuelt har et mål om, at personer med begrænset varig arbejdsevne skal udvikle denne for at deltage i arbejdsfællesskaber, skaber et spændingsfelt mellem beskæftigelsespolitiske og socialpolitiske hensigter.

Ud fra en klassisk forståelse af socialpoli$\mathrm{tik}^{2}$ kunne førtidspension (invalidepension) oprindelig siges at være en socialpolitisk kerneydelse, fordi der var tale om sikring mod indkomstbortfald som følge af et varigt tab af erhvervsevne. Der var således en gruppe, som primært ud fra helbredsmæssige kriterier kunne fritages fra pligten til at forsørge sig selv gennem arbejde.

Fra 2003 skiftede tildelingskriteriet fra erhvervsevne til arbejdsevne, hvilket var udtryk for en helt ny tankegang, hvor ideen om kompensation af tabt erhvervsevne udskiftes med tanken om muligheder for at udvikle arbejdsevnen. Dette italesættes også som et fokusskifte fra begrænsninger og barrierer til et fokus på ressourcer og muligheder.

Førtidspension kunne herefter kun komme på tale, hvis det konkret kunne dokumenteres, at det ikke var muligt at finde en arbejdsfunktion, som borgeren kunne bestride (Amby \& Schaldemose, 2018). Alle er nu som udgangspunkt forpligtet til at udnytte deres arbejdsevne, uanset hvor lille den er, og dermed kommer diskussionen om førtidspension også til i højere grad at handle om arbejdsmarkedspolitik. Der kan nemlig opstå nye behov for offentlig intervention i markedsmekanismerne for køb og salg af arbejdskraft, som er arbejdsmarkedspolitikkens hovedfunktion (jf. Bredgaard, Jørgensen, Madsen \& Rasmussen, 2017).

Ansvaret for førtidspension blev overført til beskæftigelsesministeriet i 2009 og fuldendte dermed flytningen af alle overførsels- indkomster fra socialministeriet, som blev indledt i 2001. Selv om der er bred enighed om, at det er problematisk at anvende det organisatoriske tilhørsforhold som udgangspunkt for en afgrænsning af social- og arbejdsmarkedspolitik (Bredgaard et al., 2017; Olsen \& Rasmussen, 2016), ligger der alligevel en vigtig signalværdi heri.

Ressortflytningen kan siges at være den foreløbige kulmination på en udvikling siden starten af 1990'erne, hvor arbejdsmarkedspolitiske argumenter gradvist kom til at fylde stadig mere i kriterierne for at få tilkendt førtidspension, og med den seneste reform fra 2013 er der taget yderligere skridt ad den vej.

Det leder til det andet formål, som er at belyse, hvordan politiske ideer og beslutninger over tid har ændret grundlæggende ved balancen mellem social- og arbejdsmarkedspolitik med udgangspunkt i førtidspension som eksempel. Den historiske redegørelse peger således også på de ideer og institutionelle nybrud, der tilstøder området og opnår tilslutning undervejs, hvilket forfølges i diskussionsafsnittet.

Tesen er her, at førtidspensionsområdet er et eksempel på, at der i Danmark er sket en gradvis men radikal omformning af socialpolitikken, der samtidig har ledt til en ændret forståelse af traditionelle arbejdsmarkedsbegreber som arbejde og arbejdsudbud, efterspørgsel, arbejdsstyrke samt selvforsørgelse. På den måde bliver arbejdsmarkedspolitik også noget andet i dag.

Arbejdsmarkedspolitik rettede sig oprindeligt mod personer i arbejdsstyrken for at sikre allokering, kvalificering, mobilitet, forsørgelse og det rette match mellem ledige og arbejdsgivere (Hansen, 1996). Beskæftigelsespolitik retter sig mod alle i den erhvervsaktive aldersgruppe, og ændrer således ved arbejdsmarkedspolitikkens begreber og forståelser, der er målrettet personer i arbejdsstyrken. 
Udviklingen betyder, at der er kommet større opmærksomhed på den rest arbejdsevne (arbejdskraft), som potentielle førtidspensionister er i besiddelse af og på efterspørgslen efter denne arbejdskraft. Dermed er der også etableret en tættere kobling mellem debatten om førtidspension og den generelle debat om ledighed. Førtidspensionsområdet er således også påvirket af, at social og arbejdsmarkedspolitikken over en årrække er forandret i en aktiv retning bl.a. omtalt som en bevægelse fra welfare mod workfare (Torfing, 2004). Beskæftigelse ses i stigende grad som løsning på sociale problemer, hvilket af mange også udlægges som, at socialpolitikken er presset ${ }^{3}$.

Tidligere dansk forskning om førtidspension har ved hjælp af register- og surveydata søgt at finde forklaringer på udviklingen i antallet af tilkendelser og i regionale og kommunale forskelle i tilkendelsespraksis (Bengtsson, 2002). Andre studier har med en kombination af kvantitative og kvalitative data belyst kompleksiteten i sagsforløb, som har ledt frem til tilkendelse af førtidspension, og hvilken rolle aktive redskaber spiller i kommunernes praksis på området (Caswell $\&$ Kleif, 2013). Denne artikel bidrager med et historisk overblik og sætter fokus på ændringerne i samspillet mellem socialpolitiske og arbejdsmarkedspolitiske ideer i relation til førtidspension og de mulige konsekvenser heraf.

Inden gennemgangen af de tre reformer i 1984, 2003 og 2013 følger først nogle teoretiske betragtninger og en beskrivelse af den anvendte metode. Artiklen afsluttes med diskussion og opsamling om de to teser.

\section{Teoretisk tilgang}

Til at belyse den første problemstilling anskues førtidspensionssystemet især gennem forandringer i filtreringsmekanismerne (Rold Andersen, 1971) med fokus på forandringer i tildelingsbetingelser og udmålingsbestemmelser. Redegørelsen anvendes som afsæt til analyse af nogle af reformernes konsekvenser i et medborgerperspektiv. Medborgerskabsperspektivet har med inspiration fra Marshall (2003/1950) fokus på universelle sociale rettigheder, der muliggør deltagelse i samfundslivet (Goul Andersen, 2013). Analysen her er inspireret af Esping-Andersens kobling af medborgerskab med decommodificering ${ }^{4}$ (Esping-Andersen, 1990). Gennemførelsen af sociale rettigheder hidrører fra borgeres afhængighed af som arbejdskraft at være en vare på arbejdsmarkedet. Udvikling af førtidspensionsområdet kan således betragtes som anerkendelse af ret til forsørgelse for grupper, der pga. lav erhvervsevne ikke kan sælge deres arbejdskraft på det ordinære marked. Velfærdsstaten sætter en grænse for personers afhængighed af succes på markedet. Udbygningen af førtidspensionsområdet i 1960erne har således udbygget en universel social tryghed samt styrket deltagelsesmulighederne for personer med lav erhvervsevne (Petersen, 2012). Goul Andersen peger imidlertid på det aktuelle begreb om aktivt medborgerskab som et mangesidet og modsigelsesfyldt begreb (Goul Andersen, 2013, s. 106). Medborgerskabshensynet handler dels i en klassisk forståelse om at sikre tryghed i forsørgelsen så ressourcer for den enkelte styrkes og deltagelse bliver mulig, men ligeledes om en nyere tematisering om ret og pligt til at deltage på centrale arenaer i samfundet herunder også en rekommodificering af marginale gruppers arbejdskraft. Goul Andersen fremhæver, at vurdering af reformer bør inddrage spørgsmålet om outcome i et medborgerskabsperspektiv:

"Still it should be supplemented by considerations about whether the observed changes are 'transformative' in the sense that they affect basic principles or have profound impact on outcomes, in particular on those outcomes 
that are relevant from a citizenship perspective." (Goul Andersen, 2011, s. 6).

Det er således et mål, at redegørelsen for reformerne i 1984, 2003 og 2013 også afdækker reformernes betydning for forandringer i sociale vilkår og deltagelsesmuligheder, der opstår for grupper, der står på kanten af eller får tildelt en førtidspension.

Artiklen trækker i relation til den anden problemstilling på et historisk institutionelt perspektiv. Førtidspension kan betragtes som en institution, fordi der er tale om:

"socialt sanktionerede (kollektivt håndhoevede) forventninger i forhold til bestemte aktørers adfoerd eller $i$ udøvelsen af bestemte aktiviteter" (Bredgaard, 2014, s. 41).

Især teorier om gradvis institutionel forandring er relevante i denne sammenhæng (Streek \& Thelen, 2005). Der skal nemlig argumenteres for, at udviklingen på førtidspensionsområdet siden starten af 1990'erne snarere er et resultat af en række af mindre ændringer end af få store brud. Når betegnelsen reform anvendes om lovændringerne i 1984, 2003 og 2013, skyldes det dels, at der var tale om markante lovændringer, og dels at ændringerne politisk er italesat som reformer. Fundamentet blev dog i høj grad lagt gennem beslutninger og aktiviteter $\mathrm{i}$ årene op til reformernes gennemførelse, hvilket gør det vanskeligt at tale om pludselige brud.

Ifølge Streek \& Thelen (2005) kan der identificeres forskellige typer af gradvis institutionel forandring. Sagen er nemlig, at institutioner - herunder regelsæt - kan ændre karakter og f.eks. skifte formål eller fundamentalt ændre indhold over årene. Nye institutioner kan dukke op og komme til, helt eller delvist, at fortrænge gamle institutioner. Nye elementer kan komme til og efterhånden bevirke, at en institution ændrer status. En institution kan langsomt overgå til at tjene helt nye formål, eller en institution kan over tid udspille sin rolle, fordi den oprindelige opgave er løst ( se også Bredgaard, 2014; Greve, 2012; Jørgensen, 2006; Streek og Thelen, 2005).

Artiklen analyserer ikke de politiske beslutningsprocesser eller aktørinteresser i tilknytning til de mange enkeltbeslutninger, der har haft indflydelse på indretningen af førtidspensionssystemet. Hvad angår mulige årsager til de gradvise forandringer, er der fokus på ideers betydning og de lange linjer, hvilket ikke er så centralt i Streek og Thelens begrebsapparat. I den sammenhæng hentes der inspiration fra Metha (2011), som argumenterer for, at der er et gensidigt samspil mellem politiske løsninger, problemforståelser og samfundsfilosofi eller zeitgeist. En reform af førtidspensionssystemet er nok løsningen på et aktuelt problem, men kan samtidig være et udtryk for, at problemforståelsen har skiftet over tid som følge af påvirkning fra nye idemæssige strømninger. En sådan reform kan dog også sætte nye rammer for, hvilke problemforståelser og løsninger det fremadrettet vil være muligt og legitimt at anvende på området.

Barbier peger på, at reformer i mange velfærdsstater følger en tankegang, hvor der er en ambition om at øge arbejdsstyrken og hæve arbejdsudbuddet på tværs af politikområder (Barbier, 2005; Goul Andersen, 2011). Det forekommer også som en relevant idemæssig ramme at se den danske udvikling på førtidspensionsområdet i.

\section{Metode}

Artiklen bygger på dokumentstudier. For det første anvendes en retsdogmatisk metode (Munk Hansen, 2014) til en systematisk analyse af gældende ret i vedtagne love ud fra motiverne hertil, som de er kommet til udtryk i bemærkningerne til lovforslagene og med inddragelse af forarbejder i form af 
udvalgsrapporter m.v. i perioden 1984-2013. Der er taget udgangspunkt i lovforslag og bemærkninger til reformerne og anvendt back-tracking søgning i forhold hertil. Der er søgt på høringssvar samt lovens forarbejder og baggrundsmateriale. Der er søgt på kommissionsudredninger samt udvalgsbehandlinger i relation til behandling i forhold til reformernes tildelingskriterier. Det har ikke været muligt at opdrive skriftligt materiale fra alle udvalgs behandlinger. Det er dog vurderingen, at de væsentligste dokumenter fra kommissioner og lovbehandling herved er fundet. Analysen af udviklingen i gældende ret anvendes til at beskrive forandringerne i filtreringsmekanismerne.

For det andet er love m.v., kommissionsrapporter samt videnskabelige tolkninger af udviklingen blevet analyseret som beretning. Det vil sige, at dokumenterne udover at sige noget om egen ophavssituation også kan anvendes til at drage slutninger "om virkeligheden" (Elklit og Jensen, 2012, s. 124). Dokumenterne analyseres således ud fra indholdet om de ideer, der slår igennem. Der er ved analysen af dokumenterne anvendt en meningskondenserende metode (Kvale og Brinkmann, 2016) med fokus på at fremanalysere de ideer og tankegange, der har understøttet forandring af reglers udformning. Det betyder, at det især er de kommissionsbehandlinger, bemærkninger til lovforslag mv., der senere vinder tilslutning blandt besluttende aktører, der trækkes frem. Vi forbigår hermed den række af forslag og ideer, som ikke siden vinder tilslutning.

Dokumentstudiet har primært haft fokus på skiftet fra erhvervsevne til arbejdsevne samt indførelsen af flexjob og ressourceforløb. Regler vedrørende eksempelvis beskatning og bruttofisering, tilkendelseskompetence, tillægsydelser, fradrag etc. har ikke været genstand for undersøgelsen. Kun hvor ændringen af tilkendelseskriteriet for førtidspension har haft en tæt sammenhæng med andre love, er disse blevet inddraget. Det drejer sig således om Lov om aktiv socialpolitik (Aktivloven) og i mindre grad Lov om social service (Serviceloven), der sammen med Lov om retssikkerhed og administration (Retssikkerhedsloven) på det sociale område var en del af reformen af bistandsloven i 1998.

\section{Reformer på førtidspensions- området 1984, 2003 og 2013}

Som grundlag for gennemgangen af de tre reformer i 1984, 2003 og 2013 følger først et kort historisk rids om invalidepensionssystemets etablering og udvikling. Redegørelserne for de tre reformer indeholder derefter både en beskrivelse af reformernes indhold og for udviklingen i de efterfølgende år, som ledte frem til den politiske beslutning om endnu en reform af systemet.

\section{Et historisk rids: 1921-1984}

I 1921 blev den første lov om forsikring mod invaliditet vedtaget (Lov nr. 253 af 6. maj 1921). Forud var gået årtier med diskussion af invalides rettigheder, men under indtryk af genforeningen af Sønderjylland med Danmark blev en regulær forsikringslov en realitet $^{5}$. Offentlig hjælp til forsørgelse kunne hidtil principielt kun ydes efter fattiglovgivningen. Lov om invalideforsikring medførte ret til invaliderente under visse nærmere angivne betingelser herunder medlemskab af en invalideforsikring, hvis erhvervsevnen var nedsat til en tredjedel eller derunder. I forbindelse med Kanslergadeforliget i 1933 blev reglerne for invalide og aldersrente stort set gjort ensartede jf. folkeforsikringsloven (Lov nr. 182 af 20. maj 1933). Medlemskab af invalideforsikringen blev nu gjort lovpligtig for personer mellem 21 og 60 år, der opfyldte helbredsbetingelserne.

Der skete i den følgende periode ligeledes nogle semantiske ændringer og indførelse af 
graduerede ydelser. I 1956 blev betegnelsen invalidepension indført (Lov nr. 258 af 2. oktober 1956). Samtidig blev betegnelsen aldersrente ændret til folkepension. I 1965 indførtes gradueret invalidepension (Lov nr. 219 af 4 . juni 1965), der omfattede 3 pensionsstørrelser. Berettigelsen hertil afspejlede graden af erhvervsevnenedsættelsen. Der var således allerede på dette tidspunkt forskellige niveauer i ydelsen og en tænkning om kompensation for et tab af erhvervsevne.

I løbet af 1950erne pågik en diskussion om, hvordan initiativer til at støtte og forbedre erhvervsevnen kunne udformes. Det førte til revalideringsloven i 1960 (lov nr. 170 af 29. april 1960), der sigter på:

"... at sikre fuld udnyttelse af de erhvervsmoessige muligheder ikke mindst for fysisk, psykisk og socialt handicappede... Tanken var, at en løsning af de beskaetigelsesmoessige problemer i sig selv ville bidrage til at løse andre dele af et sammensat problemkompleks dels til gavn og gloede for den enkelte, men i mange tilfaelde også som udtryk for en samfundsøkonomisk hensigtsmaessig indsats" (Petersen, 2012, s.554).

Denne forebyggende og aktivt interventionistiske tanke har et tydeligt slægtskab med de seneste reformer.

\section{Reformen i 1984 \\ og tiden frem til 2003}

I 1984 blev der indført en forenkling af førtidspensionssystemet, hvor de forskellige pensionsordninger ${ }^{6}$ skrives sammen og omtales som førtidspension. Der indførtes med reformen fire niveauer for pension: højeste, mellemste, forhøjet almindelig og almindelig førtidspension.

Personkredsen for pension fremgår af Lov nr. 217 16. maj 1984.
"§ 14. Højeste førtidspension kan tilkendes personer i alderen fra 18 til 60 år, der i ethvert erhverv må anses for kun at have ubetydelig erhvervsevne i behold.

Stk. 2. Mellemste førtidspension kan tilkendes personer $i$ alderen fra 18 til 60 år, hvis erhvervsevne er nedsat med omkring 2/3, og personer $i$ alderen fra 60 til 65 år, hvis erhvervsevne er nedsat i det omfang, der er noevnt $i$ stk. 1

Stk. 3. Forhøjet almindelig førtidspension eller almindelig førtidspension kan tilkendes personer i alderen fra 18 til 65 år, hvis erhvervsevne er nedsat på grund af helbredsmoessige forhold med mindst halvdelen, personer $i$ alderen fra 18 til 65 år, hvis erhvervsevne er nedsat med mindst halvdelen, uden at nedsaettelsen alene skyldes helbredsmoessige forhold, og personer $i$ alderen fra 50 til 65 år, når sociale og helbredsmoessige forhold taler for det."

I begyndelsen af 90erne fremkom nye ideer om et forstærket fokus på virksomhedernes rolle i forhold til at løfte et social ansvar, der blev italesat som en politisk strategi om et rummeligt arbejdsmarked. To udvalg om skånejob lagde fokus på betydningen af aftalebaserede skånejob frem for støttede jobs. Alligevel resulterede den politiske ambition om at øge det rummelige arbejdsmarked i, at der allerede i 1996 blev skrevet en ordning ind i Bistandsloven til afløsning af de tidligere støttemuligheder. I forlængelse heraf blev fleksjob opfundet i 1997, og ordningen blev en central del af socialreformen i 1998, hvor bistandsloven afskaffedes. Det har både før og efter fleksjobordningen vist sig vanskeligt at indfri ønskerne om aftalebaserede skånejobs, og antallet er aldrig blevet ret stort (Skånejobudvalg I 1995, Socialministeriet, 2007).

Fleksjob kunne på daværende tidspunkt bevilges til personer med en varigt nedsat arbejdsevne. Arbejdsgiveren modtog tilskud på $1 / 3,1 / 2$ eller $2 / 3$ af den overenskomst- 
mæssige løn. Lønmodtageren arbejdede med et skånehensyn og evt. på nedsat tid, men modtog fuld overenskomstmæssig løn. På den måde var fleksjobordningen egentligt en fuld kompensationsordning for tab af arbejdsevne. Hvis det ikke var muligt for de visiterede at finde et fleksjob, var der mulighed for en ledighedsydelse i tiden med ledighed fra et fleksjob.

Af bemærkningerne til forslag til lov om ændring af lov om social bistand og lov om dagpenge ved sygdom eller fødsel (LF nr. 270/1996) fremgik det bl.a. at:

"Lovforslaget er en del af regeringens initiativer med henblik på at udvikle et arbejdsmarked, hvor der bliver plads til grupper af personer, der ikke har en fuld arbejdsevne $i$ behold, men som kan gøre en indsats på fleksible vilkår - et rummeligt arbejdsmarked".

Det fremgik tillige, at der sigtes mod at få oprettet 30-40.000 fleksjob inden 2005. Endelig anførtes det at:

"Formålet med lovforslaget er også at begroense tilgangen til førtidspension gennem bedre forebyggelse og styrkelse af de aktive tilbud til personer, der ikke modtager social pension, og som har varige begroensninger i arbejdsevnen." (LF nr. 270/1996).

Målt i antal udvalg, udvalgsrapporter samt tiden op til reformen i 2003 har optakten og forarbejdet været både lang og omfattende. Faktisk må optakten siges at have varet mere end 10 år startende ved en række udvalg nedsat i 1988 af statsministeren med det formål at forenkle, effektivisere og afbureaukratisere den offentlige sektor (Betænkning nr. 1168/1989). Herefter fulgte arbejdsgruppen om finansiering, revalidering og førtidspension m.v., der afgav rapport i september 1990. Dernæst fulgte rapport om bruttoficering af den sociale pension (1991) førtidspensionsudvalg I (1992) og II (1996), Udvalget om hjælpemidler og andre handicapkompenserende ydelser (1996), udvalget om bistandslovens serviceydelser m.v. (1996) samt Skånejobudvalg I (1995) og II (1996/1997). Særlig betydningsfuld for den fremadrettede tænkning var førtidspensionsudvalg II (1996), der banede vejen for at skifte syn fra erhvervsevne til arbejdsevne. Rapporten lagde således grunden til udviklingen af arbejdsevnemetoden og ressourceprofilen som en krumtap i den kommende pensionsreform:

\begin{abstract}
"Med erhvervsevnekriteriet skal tabet af evnen til at klare erhvervsmaessig beskaeftigelse godtgøres. Den psykologiske effekt heraf kan vaere uhensigtsmaessig og ikke befordrende for ansøgers selvforståelse og for bestraebelserne for at fremme en fortsat tilknytning til arbejdsmarkedet - også for de personer der tilkendes en førtidspension". (Førtidspensionsudvalg II (b) 1996, s. 60).
\end{abstract}

I stedet foreslog rapporten funktionsevnekriteriet, der blev beskrevet som et positivt, fremadrettet kriterium i modsætning til erhvervsevnekriteriet:

"Funktionsevnekriteriet kan defineres som et kriterium, der saetter fokus på personens ressourcer - fx personens aktuelle og fremtidige muligheder for at udføre erhvervsmaessig beskaeftigelse og dermed opnå en almindelig indtjening. Det afgørende i dette kriterium er - hvad personen kan, og hvad personen kan bringes til at kunne. Personens mulighed for at udføre erhvervsmoessig beskaeftigelse skal vurderes $i$ forhold til enhver form for arbejde på det almindelige arbejdsmarked" (Førtidspensionsudvalg II (b) 1996, s. 61).

Funktionsevne skiftede senere navn til arbejdsevne, sandsynligvis fordi funktionsevnebegrebet også blev anvendt i service- 
loven med henblik på tildeling af personlig hjælp.

\section{Reformen i 2003 og tiden frem til 2013}

Efter en del politiske forhandlinger blev en ny førtidspensionslov vedtaget $i$ år 2000 med virkning fra 1/1-2003 (Petersen, 2014, s. 736). Det afgørende nye var skiftet fra erhvervsevnekriteriet til arbejdsevnekriteriet. Herudover indførtes en fast takst for førtidspension på dagpengeniveau for enlige og med et lavere niveau for gifte/samlevende på 85 pct. af dagpengesatsen. Formålet var, at alle med en arbejdsevne fik mulighed for at udnytte denne på arbejdsmarkedet, men at der samtidig skulle sikres en tryg forsørgelse for fremtidige førtidspensionister.

Det var endvidere et formål at styrke retssikkerheden ved at sikre en mere ensartet sagsbehandling. Den indførte arbejdsevnemetode, hvor der skulle udarbejdes en såkaldt ressourceprofil, var således et nøglepunkt i reformen. Reformen medførte derfor et omfattende efteruddannelsesprogram for alle sagsbehandlere på førtidspensionsområdet, der skulle bidrage til at kvalificere sagsbehandlingen.

Det forudsattes i reformen, at der skulle ske en halvering af tilkendelser af førtidspension som følge af reformen. Personer med varige begrænsninger i arbejdsevnen skulle fortsat deltage på arbejdsmarkedet med støtte som alternativ til førtidspension, hvis det ikke var dokumenteret umuligt.

I tillæg til den nye førtidspension skete der også justeringer af fleksjobordningen. Der indførtes en fleksydelse som en efterlønslignende ordning for fleksjobbere, der er fyldt 60 år. Desuden bortfaldt muligheden for $1 / 3$ tilskud, så der kun var to takster for lønkompensation til arbejdsgivere; $1 / 2$ eller $2 / 3$ af lønnen. Baggrunden for ændringen var bl.a. at præcisere: "at ordningen er rettet mod personer med voesentlig nedsoettelse af arbejdsevnen" (LF nr. 136/2000) samt at tydeliggøre:
"arbejdsmarkedets parters ansvar for personer med en mindre nedsaettelse af arbejdsevnen, ligesom risikoen for, at personer, der kunne have fundet ustøttet beskaftigelse omfat- tes af fleksjobordningen, mindskes" (LF nr. 136/2000).

Dette bevirkede samtidig, at grupper, der varigt har nedsættelser af arbejdsevnen under 50 pct., kunne komme i en forsørgelsesmæssig klemme uden fuld arbejdstid men samtidig uden ret til offentlige ydelser.

Som følge af god succes med tilstrømning til fleksjobordningen og betydelige offentlige udgifter forbundet hermed kom en justering i 2006, der skulle tilskynde til en bedre visitering og færre på ledighedsydelse.

I 2007 viste en redegørelse om førtidspensionsreformen, at der var problemer med målopfyldelsen og betydelige merudgifter i forhold til forudsætningerne i 2003 reformen. Følgende hovedkonklusion blev fremhævet i redegørelsen:

"Antallet af personer visiteret til støttet beskoeftigelse er steget markant, uden at det har ført til foerre tilkendelser af førtidspension end $i$ 2001. Der er derved sket en voesentlig udvidelse af den samlede gruppe på fleksjob, ledighedsydelse og førtidspension". (Socialministeriet mv. 2007, s. 5)

Dette banede vejen for en ny reform, der aftaltes i 2012 med ikrafttrædelse i 2013. Den nye reform var idemæssigt især inspireret af arbejdsmarkedskommissionens forslag fra 2009 samt en evaluering af arbejdsevnemetoden, som konsulenthuset DISCUS foretog i 2010.

Arbejdsmarkedskommissionen skulle komme med konkrete forslag til, hvordan der kunne skabes yderligere fremgang i ar- 
bejdsudbud og beskæftigelse med det udgangspunkt, at beskæftigelse er en forudsætning for velfærd. Kommissionen skulle herunder også beskæftige sig med rummelighed på arbejdsmarkedet. I kommissoriet hedder det bl.a.:

\begin{abstract}
"Regeringens vision indeboerer bl.a. en større rummelighed på arbejdsmarkedet, hvor personer med nedsat arbejdsevne skal have mulighed for at bruge deres evner og deltage $i$ arbejdslivet. I de senere år har bestroebelserne på at skabe mere rummelighed på arbejdsmarkedet bl.a. givet sig udslag $i$ en markant stigning $i$ antallet af personer visiteret til fleksjob. Det er sket uden, at det har fort til foerre tilkendelser til førtidspension eller foerre sygedagpengemodtagere. Regeringens vision for det rummelige arbejdsmarked bygger på en mere klar målretning af de offentlige ordninger for personer med nedsat arbejdsevne, herunder at fleksjob forbeholdes personer, der ikke kan bringes i ustøttet beskoeftigelse og at førtidspension forbeholdes personer, der ikke kan bringes i støttet beskaeftigelse." (Arbejdsmarkedskommissionen, 2009, s. 37).
\end{abstract}

Med henblik på at forebygge førtidspension foreslår kommissionen bl.a. at der indføres udviklingsforløb for personer, som aktuelt har en ubetydelig arbejdsevne, men hvor der er mulighed for at udvikle arbejdsevnen. Desuden foreslår kommissionen en omlægning af fleksjobordningen, som omfatter en ændret tilskudsmodel, og giver mulighed for fleksjobs på få timer om ugen.

Formålet med analysen fra DISCUS var at kortlægge om arbejdsevnemetoden blev anvendt til at understøtte en fremadskridende udviklende proces og hvorvidt metoden:

"medvirker til at mennesker med mulighed for aktuel eller fremtidig (gen)indtroeden på arbejdsmarkedet tildeles permanente ydelser" (DISCUS, 2010, s. 5).
Konklusionen i evalueringen var, at der i langt overvejende grad var fokus på barrierer frem for ressourcer i de gennemgåede ressourceprofiler, og profilerne i langt overvejende grad benyttedes som dokumentationsredskab frem for et udviklingsredskab. Dette skulle ses i sammenhæng med:

"at arbejdsevnemetoden og ressourceprofilen er født som nøglen til at få en offentlig ydelse, og at man ikke kan få disse ydelser uden en solid dokumentation for nedsat arbejdsevne. Evalueringen viser, at man ikke kan se metoden isoleret fra denne funktion, og fra de ydelser den giver adgang til. Den ideelle betragtning, om at anvende ressourceprofilen som et udviklingsvaerktøj for borgerens ressourcer, samtidig med at den evt. på et senere tidspunkt skal anvendes som dokumentation (kontrol) af borgerens manglende ressourcer, har vist sig ikke at kunne håndteres i praksis" (DISCUS, 2010, s. 10).

Helt overordnet konkluderedes det i rapporten at:

"Hovedbegrundelsen for at introducere og udbrede arbejdsevnemetoden - at der skulle ske et voerdiskifte fra beskrivelse af barrierer til udvikling af ressourcer - er således ikke indfriet" (DISCUS, 2010, s. 7)

\section{Reformen i 2013 og frem til 2018}

2013 reformen lægger sig i forlængelse af disse anbefalinger. Arbejdsevnemetoden afskaffes, og der indføres en rehabiliteringsplan, der i højere grad skal understøtte udviklingsperspektivet $^{8}$. Rehabiliteringsplanen skal forelægges nyoprettede rehabiliteringsteams, der skal foretage en tværfaglig vurdering, der kan udvikle borgerens arbejdsevne.

Der indføres nye såkaldte ressourceforløb, der minder om de udviklingsforløb, Arbejdsmarkedskommissionen foreslog. Ressource- 
forløb kan bevilges for et til fem år ad gangen og skal bestå af en helhedsorienteret og tværfagligt koordineret indsats. Førtidspension kan som udgangspunkt ikke bevilges til unge under 40 år, der i stedet skal tilbydes ressourceforløb. Hvis det er helt åbenlyst, at arbejdsevnen ikke kan udvikles, kan unge under 40 dog bevilges førtidspension (jf. den politiske aftale om fleksjob og førtidspension fra 2012).

Fleksjobordningen ændres, så der ikke længere gives tilskud til arbejdsgiveren. Arbejdsgiveren skal i stedet udbetale løn for de effektive arbejdstimer. Borgeren modtager et fleksløntilskud for de timer, denne ikke opnår en løn. Samlet set omlægges fleksjobordningen således fra at være en fuldt kompenserende ordning til en noget mindre generøs ordning, der udgør en stor del af den forventede besparelse på 2,9 mia. om året. Med ændringen i fleksjobordningen kommer også et øget fokus på borgere med store begrænsninger i arbejdsevnen og mulighederne for at udvikle arbejdsevnen for disse grupper. Fleksjob har således ikke nogen nedre ugentlig arbejdstid, hvis blot der er et udviklingsperspektiv.

Det er derfor også forandringen af fleksjobordningen og indførelsen af ressourceforløbene, der udgør den reelle forandring af adgangen til førtidspension, der fremadrettet forbeholdes personer varigt uden arbejdsevne og uden udviklingsmuligheder.

Reformen afstedkom jf. intentionerne et stort fald i nye tilkendelser til førtidspension (Deloitte, 2018). Der har imidlertid været en omfattende pressedækning af sager, der virkede urimelige, samt afdækning af forskellige kommuners noget forskellige administration af reglerne. Dette har ført til en præcisering af kriterierne i 2018 samt mulige yderligere justeringer som følge af den omfattende evaluering i 2018 (Deloitte 2018). Men der er ingen tvivl om at fokus på, at udviklingsmulighederne skal være åben- bart formålsløse også giver et stort fortolkningsrum, som det er vanskeligt at fastlægge grænserne for ${ }^{9}$.

\section{Opsamling om udviklingen på førtidspensionsområdet}

Skemaet nedenfor opsummerer de væsentligste forskelle og ligheder i de tre førtidspensionsreformer. Indledningsvist er fokus på udviklingen i tildelingskriterier og udmålingsbestemmelser. Den første store forandring er ændringen af selve tildelingskriteriet fra erhvervsevne til arbejdsevne. Selvom de to ord lyder meget ens, er skiftet udtryk for en forandring i de grundlæggende ideer. Ved vurdering af nedsat erhvervsevne tages der udgangspunkt $i$, hvad indtjeningen er på et gældende tidspunkt for en person i en bestemt alder og med en bestemt uddannelse og erhverv. Dette sammenlignes med personen, der har en muligt nedsat erhvervsevne som følge af fysisk eller psykisk invaliditet ${ }^{10}$. Hvis erhvervsevnen således vurderes at være mere end 50 pct. nedsat, er der grundlag for en pensionstilkendelse frem til ændringen i 2003.

Arbejdsevnen defineres i bekendtgørelse nr. 543 af 28. maj 2002 således:

\begin{abstract}
"Ved arbejdsevne forstås evnen til at kunne opfylde de krav, der stilles på arbejdsmarkedet til at kunne udføre forskellige konkret specificerede arbejdsopgaver med henblik på at opnå indtoegt til hel eller delvis selvforsørgelse". ${ }^{11}$
\end{abstract}

Det betyder, at et skifte fra erhvervsevne til arbejdsevne går fra en vurdering af, hvad man ikke kan til, hvad man faktisk kan. Populært formuleres det som et skifte fra at have fokus på begrænsninger og problemer til at have fokus på ressourcer og muligheder. For at få førtidspension skulle arbejdsevnen nu være så begrænset, at der ikke kunne findes arbejdsfunktioner, som den pågælden- 
de kunne varetage hverken på det ordinære arbejdsmarked eller i fleksjob. I forbindelse med reformen i 2003 blev det understreget, at arbejdsevne skulle betragtes som et dynamisk begreb, der hele tiden er under forandring i forhold til det aktuelle arbejdsmarked (LF nr. 137/2000). Alvorlig invaliditet giver altså ikke længere i sig selv adgang til at få tilkendt førtidspension. Førtidspension kan herefter først komme på tale, hvis det konkret kan dokumenteres, at det ikke er muligt at finde en arbejdsfunktion, som borgeren kan bestride.

Rent praktisk sker der således med 2003 reformen en indsnævring af målgruppen for førtidspension. Hvor det tidligere var muligt at modtage pension, selvom man stadig kunne arbejde op til 50 pct., bliver det reelle nye kriterie de, som ikke kan visiteres til et fleksjob. Da fleksjobreglerne i 2003 baserede sig på en kompensation til arbejdsgiverne af $1 / 2$ eller 2/3 af lønnen, var det vanskeligt at henvise til et fleksjob, hvis borgeren varigt kunne arbejde mindre end $1 / 3$ effektiv arbejdstid. Dvs. at personer, der varigt havde vanskeligt ved at arbejde mere end 12 timer ugentligt, ikke ville blive henvist til fleksjob, men derimod stod til at kunne få bevilget en førtidspension.

Dette skærpes endnu engang med 2013 reformen, hvor der med ændringen af fleksjobordningen og indførelsen af ressourceforløb reelt sker en stramning i adgangen til førtidspension. Med 2013 reformen er målgruppen for førtidspension nu de, som har varigt nedsat arbejdsevne og med ingen udsigt til, at arbejdsevnen kan udvikles. 2013 reformens betoning af udvikling giver mulighed for tilkendelse af fleksjob ned til meget kort tid om ugen ${ }^{12}$. Hermed bliver grænsen for, hvor lidt man kan arbejde om ugen, før man er berettiget til førtidspension udvisket. Det afgørende bliver, om der er mulighed for, at arbejdsevnen på sigt kan udvikles til et rimeligt niveau, hvilket så ikke anno 2018 er entydigt fastlagt $\mathrm{t}^{13}$.

Den anden store forandring er udmålingen af førtidspension. 1984-reformen baserede sig på fire forskellige niveauer for førtidspension. Niveauerne var tænkt som den kompensation, der var relevant for graden af den tabte erhvervsevne. Den højeste var baseret på 100 pct. kompensation, den mellemste på $2 / 3$ og de to mindste på $1 / 2$ kompensation. Ordningerne var endvidere baseret på forskellige typer af tillæg, så der reelt fremkom fire forskellige takster for førtidspension. Med reformen i 2003 forenkles ydelsessystemet til en fast ydelse på dagpengeniveau for enlige, mens ydelsen for gifte og samlevende er lavere. Dette udmålingssystem er videreført med 2013 reformen. Forandringen i ydelsesstruktur fra 1984 er ikke helt sammenlignelig, da en række tilskud samtidig er bortfaldet, men umiddelbart er et niveau på dagpengeniveau lavere end højeste førtidspension men højere end mellemste førtidspension i 1984 reformen og betydeligt højere end almindelig forhøjet og almindelig førtidspension.

En samlet tolkning af tildelings- og udmålingssystemet er, at målgruppen for førtidspension er betydeligt indsnævret men trygheden sikret for den snævre målgruppe. Færre skal have førtidspension, så der kommer en større gruppe med varige begrænsninger i arbejdsevnen, som ikke kan få førtidspension. Indførelsen af 2003 reformen kan anskues som en nedtoning af at kompensere borgere for et tab og med en stærkere pligt til at deltage i aktive tilbud for at udvikle og dokumentere arbejdsevnen. Ydelsesniveauet på førtidspension fastholdt dog en ambition om at sikre trygheden, også i en erkendelse af at ganske få faktisk udnyttede deres resterhvervsevne. Samlet set er der snarere tale om stramning af tildelingskriterierne end af udmålingsbestemmelserne. 
I et medborgerskabsperspektiv er der fokus på, at alle har mulighed for at deltage i samfundslivet og det politiske fællesskab. Det sociale medborgerskab sikres (jf. Marshall, 2003) ved, at alle grupper har de nødvendige ressourcer for at kunne deltage. Med beskæftigelsespolitikkens fokus på mulig arbejdsevne er fokus imidlertid også på borgerens mulige deltagelse i et arbejdsfællesskab, som en central værdi i livet (se f.eks. bemærkningerne til LF nr. 53/2012). Det har siden 1950erne også været et socialpolitisk mål, men rækkevidden af hvem, det omfattede, var snævrere. I socialpolitikken tolkes deltagelse således bredere og med fokus på at understøtte egne muligheder og potentialer i livet med en basal forsørgelse som grundlag for grupper, der ikke kan være selvforsørgende ${ }^{14}$.

Tesen er, at de ændrede tildelingskriterier, der formelt set aktuelt har et mål om, at personer med begrænset varig arbejdsevne skal udvikle denne for at deltage i arbejdsfællesskaber, skaber et spændingsfelt mellem beskæftigelsespolitiske og socialpolitiske hensigter.

Der er således et spændingsfelt mellem de beskæftigelsespolitiske og socialpolitiske hensigter, hvor pligten til at udbyde sin arbejdskraft i dag står centralt og i stedet prioriteres højere end f.eks. at deltage i fritidsaktiviteter. Der kan derfor opstå en vanskelig balance mellem ressourcer til at arbejde og ressourcer til at leve livet og klare sig selv så vidt muligt for udsatte grupper med alvorlige helbredsproblemer. Diskussionen af denne balance forekommer ligeledes som hovedindtryk i den positive brugerevaluering af fleksjobordningen, en mere blandet brugerevaluering af ressourceforløbene (Deloitte, 2018), samt den omfattende debat om jobcenterets skadelige virkninger for personer med helbredsprobleme ${ }^{15}$. Der har bl.a. været rejst kritik af, at alvorligt kronisk syge har skullet deltage i ressourceforløb i stedet for at få bevilget førtidspension. Den seneste justering eller præcisering af førtidspensionsordningen i 2018 har således også til hensigt, at kommunernes administration lægger et andet snit mellem ressourceforløb og førtidspension. Tilbage står, at pligten til at udbyde sin arbejdskraft med arbejdsevneforståelsen er blevet mere omfattende og uden en klar nedre grænse. På den måde er der tale om en rekommodificering.

Tabel X: Skema om udvikling på førtidspensionsområdet

\begin{tabular}{llll} 
Tildelingskriterie & 1984-reformen & 2003-reformen & 2013-reformen \\
& $\begin{array}{l}\text { Erhvervsevnen varigt } \\
\text { nedsat }\end{array}$ & $\begin{array}{l}\text { Arbejdsevnen } \\
\text { varigt nedsat }\end{array}$ & $\begin{array}{l}\text { Arbejdsevnen varigt } \\
\text { nedsat }\end{array}$ \\
\hline Reelt tildelingskriterie & $\begin{array}{l}\text { Mere end 50 pct. } \\
\text { nedsat erhvervsevne }\end{array}$ & $\begin{array}{l}\text { Mere end 2/3 } \\
\text { begrænset } \\
\text { arbejdsevne }\end{array}$ & $\begin{array}{l}\text { Varigt uden } \\
\text { arbejdsevne og uden } \\
\text { mulighed for udvikling } \\
\text { af arbejdsevne }\end{array}$ \\
\hline $\begin{array}{l}\text { Definition af centralt } \\
\text { begreb }\end{array}$ & $\begin{array}{l}\text { Erhvervsevne: Når } \\
\text { den enkelte kan } \\
\text { udføre erhvervet } \\
\text { som normalt }\end{array}$ & $\begin{array}{l}\text { Arbejdsevne: } \\
\text { krav til at kunne } \\
\text { udføre forskellige } \\
\text { konkret specifi- } \\
\text { cerede arbejds- } \\
\text { opgaver }\end{array}$ & $\begin{array}{l}\text { Ingen hjemlet } \\
\text { arbejdsevne }\end{array}$ \\
\hline
\end{tabular}




\begin{tabular}{|c|c|c|c|}
\hline Ydelse & 4 niveauer & $\begin{array}{l}1 \text { niveau } \\
\text { (afhængig af civil } \\
\text { status) }\end{array}$ & $\begin{array}{l}1 \text { niveau (afhængig af } \\
\text { civil status) }\end{array}$ \\
\hline Socialpolitiske tankegange & $\begin{array}{l}\text { Forebyggelse af tab } \\
\text { af erhvervsevne ved } \\
\text { anvendelse af revali- } \\
\text { dering } \\
\text { Kompensation af et } \\
\text { tab af en beregnet } \\
\text { erhvervsevne }\end{array}$ & $\begin{array}{l}\text { Fokus på ressour- } \\
\text { cer og mulig- } \\
\text { heder for delvis } \\
\text { selvforsørgelse } \\
\text { ved anvendelse } \\
\text { af aktive tiltag og } \\
\text { især fleksjob } \\
\text { Forsørgelse på } \\
\text { dagpengeniveau }\end{array}$ & $\begin{array}{l}\text { Afprøvning af alle } \\
\text { udviklingsmuligheder } \\
\text { ved ressourceforløb og } \\
\text { fleksjob før tilkendelse } \\
\text { af førtidspension } \\
\text { Forsørgelse på } \\
\text { dagpengeniveau }\end{array}$ \\
\hline $\begin{array}{l}\text { Muligheder for personer } \\
\text { med en truet arbejdsevne }\end{array}$ & $\begin{array}{l}\text { Fuld selvforsørgelse } \\
\text { Førtidspension } \\
\text { med mulighed } \\
\text { for at arbejde }\end{array}$ & $\begin{array}{l}\text { Fuld } \\
\text { selvforsørgelse } \\
\text { Delvis selvfor- } \\
\text { sørgelse med } \\
\text { fleksjob over } \\
12 \text { timer } \\
\text { Førtidspension } \\
\text { med mulighed } \\
\text { for at arbejde }\end{array}$ & $\begin{array}{l}\text { Fuld selvforsørgelse } \\
\text { Ressourceforløb } \\
\text { Delvis selvforsørgelse } \\
\text { med fleksjob ned til } \\
\text { få timer om ugen } \\
\text { Førtidspension } \\
\text { (med mulighed } \\
\text { for at arbejde) }\end{array}$ \\
\hline Sagsbehandling & Metodefrihed & $\begin{array}{l}\text { Arbejdsevne- } \\
\text { metoden med } \\
\text { ressourceprofil }\end{array}$ & $\begin{array}{l}\text { Rehabiliterings- } \\
\text { planen }\end{array}$ \\
\hline
\end{tabular}

\section{Diskussion}

Formålet med diskussionsafsnittet er, med afsæt i beskrivelsen af udviklingen af førtidspension, at diskutere forandringer i social og arbejdsmarkedspolitikken. Det sker med inspiration fra teorier om gradvis forandring og ideers betydning, jf. afsnit 2 .

Den arbejdsmarkedspolitiske og socialpolitiske udvikling har fulgt et spor, hvor der frem til 2 . verdenskrig var to systemer med en dominerende socialpolitisk målsætning. Efter 2. verdenskrig etableredes to systemer og to distinkte politikker markeret ved to ministerier, adskilte målgrupper og adskilte målsætninger. I løbet af 1990erne forandres de to systemer med en tilnærmelse og integration af politikområder (Damgaard, 2003), og senest smelter de to systemer sammen endeligt i 2009 i de kommunale jobcentre med en dominerende beskæftigelsespolitik for alle i den erhvervsaktive alder.

Udviklingen kendetegner også forløbet for førtidspensionsordningen, der i udgangspunktet var en socialpolitisk ordning, der i dag er en del af beskæftigelsessystemet. Den detaljerede gennemgang af førtidspensionsområdet giver et grundlag for at overveje de arbejdsmarkedspolitiske og socialpolitiske grundbegreber ved overgangen til beskæftigelsespolitik.

Med forskydningen i systemer og politik opstår nye spørgsmål om traditionelle arbejdsmarkedspolitiske begreber som ar- 
bejdsstyrke, arbejdsudbud og selvforsørgelse. Arbejdsstyrke defineres som de personer i de erhvervsaktive aldersgrupper, som enten er i beskæftigelse eller ledige. Med ledige henvises normalt til de personer, som er registreret ledige og modtager kontanthjælp eller arbejdsløshedsdagpenge, og står fuldt til rådighed for arbejdsmarkedet. Uden for arbejdsstyrken er således de grupper, der midlertidigt eller varigt ikke står til rådighed for arbejdsmarkedet. Det er imidlertid karakteristisk, at alle grupper, der ikke er bevilget førtidspension eller efterløn, skal stå til rådighed for en beskæftigelsesrettet indsats, hvis de vil modtage ydelser. Dvs. at stå uden for arbejdsstyrken ikke nødvendigvis betyder, at der ikke er en indsats, der henregner personen som arbejdsudbud faktisk eller potentielt. Det er således heller ikke enkelt at opgøre, hvem der faktisk er i arbejde, eller hvem der faktisk er i en type støttet beskæftigelse.

Fleksjobordningen er f.eks. svær at placere efter gængse kriterier om socialpolitiske ydelser og beskæftigelse. Den blev oprindelig etableret som en del af den sociale lovgivning som en videreudvikling af løntilskudsordninger med tilknytning til revalideringssystemet. Men faktisk kunne fleksjobordningen fra starten også siges at være etableret som en markedskorrigerende ordning, fordi den gav arbejdsgiverne mulighed for at beholde arbejdskraft, som ikke levede op til de gængse produktivitetskrav. Med de seneste ændringer kan man til gengæld argumentere for, at der nu snarere er tale om en socialpolitisk ordning, som giver lønmodtagere med nedsat arbejdsevne et forsørgelsestilskud, som gør det muligt at opretholde et rimeligt leveniveau på trods af en lille arbejdsindkomst.

Det er imidlertid også muligt at betragte forandringen af fleksjobordningen med udgangspunkt i dansk handicappolitik. Oprindelig var fleksjobordningen i fuld overens- stemmelse med et af de bærende principper heri, hvorefter mennesker med handicap skal kompenseres for at give dem mulighed for at leve et liv som alle andre. Den seneste udvikling kan ses som en bevægelse væk fra kompensationsprincippet. Nu betragtes personer med varige begrænsninger i arbejdsevnen i stedet som ledige, der får et supplerende tilskud for de timer, der ikke arbejdes. Der kan således argumenteres flere veje i den socialpolitiske og arbejdsmarkedspolitiske retorik.

Den beskrevne forandring følger også af et skifte i social- og arbejdsmarkedspolitisk syn. For en umiddelbar betragtning er forskellen måske ikke så stor. Revalideringsloven fra 1960 havde til hensigt at forebygge førtidspension. Målet var således allerede fra 1950erne, at beskæftigelsen skulle være så høj som mulig, og det politiske mål var at forebygge, at borgere havde behov for at modtage førtidspension. Det blev allerede på daværende tidspunkt fremført, at deltagelse på arbejdsmarkedet havde en væsentlig funktion for den enkeltes velfærd (Petersen, 2012, s. 554-555). Der har således været kontinuitet om denne ambition siden 1950erne.

Målet om forebyggelse af førtidspension er således stadig gældende, men er samtidig fulgt af en forandring af arbejdsbegrebet og forståelsen af selvforsørgelse. Mulighederne for borgeren stod med 1984 reformen reelt mellem selvforsørgelse gennem beskæftigelse på det ordinære arbejdsmarked eller førtidspension. Med fleksjobordningen og især med udviklingen af de mange mini-fleksjob på meget få timer om ugen efter reformen $\mathrm{i}$ 2013 kan selvforsørgelse nu også være af en meget beskeden størrelse med en betydelig offentlig støtte gennem fleksløntilskud. Begreber om arbejde og selvforsørgelse får således en gråzonekarakter, hvor arbejde også er ikke ordinært arbejde, og selvforsørgelse også er stærkt offentligt støttet. Det betyder samtidig, at det måske ikke længere giver 
mening at operere med en skarp sondring mellem det arbejdsbaserede og det behovsbaserede fordelingssystem eller mellem arbejdsmarkedspolitik og socialpolitik.

Udviklingen berører således også begrebet om arbejdsudbud. I den traditionelle forståelse opgøres arbejdsudbuddet som arbejdsstyrken. Men hvis alle, der kan arbejde ned til få timer om ugen, er en del af arbejdsudbuddet, så ændres grundsondringen mellem personer i arbejdsstyrken og personer uden for arbejdsstyrken og dermed også arbejdsmarkedspolitikkens egentlige målgruppe.

Det følger således nu også af beskæftigelsespolitikken, at der gøres en ihærdig beskæftigelsesrettet indsats for de grupper, der ikke umiddelbart kan konkurrere med det almindelige arbejdsudbud. Samtidig betyder fleksjobordningen og især de seneste ændringer heraf også forandringer på efterspørgselssiden. Indretningen af disse regler har betydet etablering af et nyt (rummeligt) arbejdsmarked, hvor der efterspørges arbejdskraft til ansættelse på få timer om ugen i forvisning om et supplerende forsørgelsestilskud. Det kan derfor også diskuteres, om det ikke er en arbejdsmarkedspolitisk opgave at sikre balance også på dette arbejdsmarked og at bidrage til et fornuftigt forhold mellem det ordinære og det rummelige arbejdsmarked.

\section{Konklusion}

Denne artikel har redegjort for udviklingen på førtidspensionsområdet med et fokus på reformerne i 1984, 2003 og 2013. Som nævnt i indledningen har det været formålet dels at belyse forandringer af førtidspension med fokus på adgang til forsørgelse og muligheder for deltagelse, dels at belyse, hvordan politiske ideer og beslutninger over tid har ændret grundlæggende ved balancen mellem social- og arbejdsmarkedspolitik.
Det er vist, hvordan især tildelingsbetingelserne er strammet betydeligt henover perioden, mens udmålingsbestemmelsen er blevet omlagt. Samlet set er pligten til at udbyde sin arbejdsevne, selv når denne er stærkt begrænset, blevet et omdrejningspunkt imellem det arbejdsbaserede og det behovsbaserede fordelingssystem. På den måde er udviklingen på førtidspensionsområdet i tråd med mere generelle politiske ideer om at øge arbejdsudbuddet og aktivere den sociale sikring. Hermed kommer en betoning af en socialpolitisk kompensationstanke i baggrunden.

Det er en anselig udvikling, vi har været vidne til: Fra en situation, hvor en del af befolkningen på grund af tab af erhvervsevne kunne bevilges permanent forsørgelse og fritages for pligten til at arbejde, til en situation hvor alle i princippet skal i beskæftigelse, men hvor selv få timers arbejde om ugen kan være tilstrækkeligt til at opfylde dette krav. Arbejde er dermed ikke længere ensbetydende med selvforsørgelse, og målet om og pligten til arbejde er udstrakt til store grupper uden for den traditionelle arbejdsstyrke. Dette berører konsekvenser for medborgerskabet, der er temaet i den omfattende politiske debat om førtidspensionen aktuelt. At fokus på arbejdsevne og selvforsørgelse for nogle borgere kan bidrage til en positiv deltagelse og identitet i relation til en arbejdsmarkedsarena, men samtidig for andre medvirker til et forringet liv med sværere deltagelsesbetingelser, synes at være konsekvenserne af udviklingen.

Forebyggelsestanken har en lang historie med revalideringsloven fra 1960 som en central kerne, men udviklingen har gradvist medvirket til en forandring af begreber om arbejdsudbud og arbejdsstyrke og dermed også rykket ved den klassiske arbejdsmarkedspolitik. Hvor revalidering skulle bidrage til, at borgere med begrænsninger igennem 
en indsats kunne blive fuldt selvforsørgende, er tanken i dag, at selvforsørgelse kan bestå af udnyttelse og udvikling af en undertiden meget begrænset arbejdsevne, der suppleres af en offentlig ydelse.

På den måde bliver grænsen mellem personer i og uden for arbejdsstyrken mere flydende, da store grupper uden for den traditionelle arbejdsstyrke skal stå til rådighed for en beskæftigelsesrettet indsats. Beskæftigelsespolitik retter sig således mod alle i de erhvervsaktive aldersgrupper, hvilket både presser en traditionel socialpolitisk forståelse men også presser en klassisk arbejdsmarkedspolitik. Beskæftigelsespolitik griber således også ind i markedet med forsøg på dannelse af et marked for udbud af og efterspørgsel efter arbejdskraft blandt personer med en varig meget begrænset men foranderlig arbejdsevne.

Udviklingen på førtidspensionsområdet kan karakteriseres på forskellige måder med afsæt i teorierne om gradvis forandring. Det er fortsat formålet med førtidspension at sikre forsørgelse til en gruppe, som er udelukket fra at forsørge sig selv. I og med at definitionen af denne gruppe har ændret sig så markant, som tilfældet er, kan ordningens formål alligevel siges at have skiftet karakter. Overordnet er der sket en fortrængning af målsætningen om at ville kompensere et erhvervsevnetab til at ville udvikle en arbejdsevne. Dette hænger sammen med fortællingen om en generel fortrængning af en passiv (welfare) politik til fordel for en aktiv (workfare) linje, der er bredt politisk understøttet. Forandringer i en ordning som førtidspension kan derfor ikke isoleres fra den generelle tidsånd (Metha, 2011).

Samtidig kan etableringen og udviklingen af fleksjobordningen anskues som lagdeling og senere konvertering (Streek og Thelen, 2005), hvor en ny ordning gennem institutionelle forandringer medfører, at førtidspension spiller en helt anden rolle end tidligere. Fleksjob indføres som nyt lag for at understøtte et rummeligt arbejdsmarked for personer med nedsat arbejdsevne, men konverterer med reformen i 2013 til at blive grænsen for det reelle nye tildelingskriterie til førtidspension. På samme måde kan ressourceforløbet anskues som en ny lagdeling relateret til førtidspension, som det endnu er for tidligt at drage langsigtede konklusioner om. Forandringen på førtidspensionsområdet er således bl.a. gennemført med introduktion af ordninger som fleksjob og ressourceforløb. På den måde har nye lagdelinger og forandringer heri rykket ved førtidspensionens placering og rolle.

Udviklingen har gradvist forandret førtidspensionsområdet fra en klassisk socialpolitisk ydelse til at være indlejret i et beskæftigelsespolitisk felt, og det er ændringer inden for flere politikområder, der tilsammen har ført til den store forandring over det lange tidsforløb. Aktuelt er gennemført en større evaluering af førtidspensionsreformen fra 2013, der som en kilde kan give grundlag for nye gradvise forandringer på feltet (Deloitte, 2018).

\section{LITTERATUR}

Amby, F. \& Schaldemose, S. (2018). Fra erhvervsevne til arbejdsevne. Arbejdsnotat: VIA.

Arbejdsevnebekendtgørelsen. Bek. nr. 543 af 28. maj 2002, Bekendtgørelse om beskrivelse, udvikling og vurdering af arbejdsevne.

Arbejdsmarkedskommissionen (2009). Velfoerd kroever arbejde. (www.amkom.dk).

Barbier, J.-C. (2005). Activation social protection and employment insurance. TLM.net, working paper no 2005-26.

Bengtsson, S. (2002). Bestemmer forvaltningen om du får førtidspension? Kbh.: SFI 02:15.

Bredgaard, T. (2014). Virksomhedernes sociale ansvar - et studie i politisk forandring: Aalborg Universitetsforlag. 
Bredgaard, T., Jørgensen H., Madsen, P. K. og Rasmussen S. (2017). Dansk arbejdsmarkedspolitik: Jurist- og Økonomforbundets forlag.

CASA (2011). Social årsrapport 2011. Kbh.: Socialpolitisk forening og CASA.

Caswell, D. \& Kleif, H. B. (2013). Disability Pensions and Active Labor Market Policy. I Journal of Social Service Research, 39, s. 572-584, DOI: 10.1080/01488376.2013.794759

Damgaard, B. (2013). Social- og arbejdsmarkedssystemerne. En flerstrenget historie. København: SFI 03:21.

Deloitte (2018). Evaluering af reform af førtidspension og fleksjob: Hovedrapport: STAR.

DISCUS (2010). Evaluering af arbejdsevnemetoden.

Elklit, J. og Jensen, H. (2012). Kvalitative datakilder. I Bøgh Andersen, L. et.al., Metoder $i$ statskundskab. Kbh.: Hans Reitzels forlag.

Esping-Andersen, G. (1990). The three worlds of welfare capitalism. Cambridge: Policy Press.

Førtidspensionsudvalg II (b) (1996). 2. rapport førtidspension tilkendelser og forenkling, Socialministeriet, maj 1996.

Goul Andersen, J. (2011). "Activation" of Social and Labour Market Policies in the Nordic Countries, 1990-2010. CCWS working paper no. 2011-71.

Goul Andersen, J. (2013). Medborgerskab under pres. I Guldager, J. Og Skytte M (red), Socialt arbejde - teorier og perspektiver. Kbh.: Akademisk forlag.

Greve, C. (2012). Reformanalyse - Hvordan den offentlige sektor grundloeggende er blevet forandret $i$ OO'erne. Jurist- og Økonomforbundets forlag.

Hansen, C. m.fl. (1996). Ta teten i arbejdsmarkedspolitikken. LO.

Hohnen, P. (2009). Fra "social klient" til "uansættelig" - Hvad betyder ændringerne i beskæftigelsespolitikken for udsatte grupper? I Udsat for forståelse. Kbh.: Rådet for socialt udsatte.

Jørgensen, H. (2006). "Arbejdsmarkedspolitikkens fornyelse - innovation eller trussel mod dansk "Flexicurity". LO og FTF.

Klausen, J. (2017). Førtidspension. I Klausen, J. et al. (red), Socialret. Forsørgelse og beskaeftigelse. Kbh.: Jurist og økonomforbundets forlag.
Kvale, S. og Brinkmann, S. (2016). Interview: det kvalitative forskningsinterview som håndvoerk. Kbh.: Hans Reitzels forlag.

Lov nr. 253 af 6. maj 1921 om invalideforsikring. Lov nr. 182 af 20. maj 1933. Lov om folkeforsikring.

Lov nr. 258 af 2. oktober 1956. Lov om folkeforsikring.

Lov nr. 219 af 4. juni 1965. Lov om invalidepension $\mathrm{mv}$.

Lov nr. 170 af 29. april 1960. Revalideringsloven.

Lov nr. 217 af 16. maj 1984. Lov om social pension.

Lovforslag nr. 270 fremsat 14. maj 1997. Lov om ændring af lov om social bistand og lov om dagpenge ved sygdom eller fødsel.

Lovforslag nr. 136 fremsat d. 15. december 2000. Forslag til lov om ændring af lov om aktiv socialpolitik og andre love. (ændring af reglerne om fleksjob, ledighedsydelse, sagsbehandling m.v.)

Lovforslag nr. 137 fremsat d. 15. december 2000. Forslag til Lov om ændring af lov om social pension og andre love.Marshall, T. S. (2003/1950). Medborgerskab og social klasse. Kbh.: Hans Reitzels forlag.

Mehta, J. (2011). The Varied Roles of Ideas in Politics: From "Whether" to "How". I Beland D. \& Cox R. H. (red.), Ideas and Politics in Social Science Research (s. 23-46). New York: Oxford University Press.

Munk-Hansen, C. (2014). Retsvidenskabsteori. København: Jurist- og Økonomforbundets Forlag.

Olsen, C. B. og Rasmussen, N. (2016). Socialpolitik: Et bud på en definition. I Hornemann Møller, I. og Larsen, J. E. (red.), Socialpolitik: Hans Reitzels forlag.

Petersen, J. H. (2011). Dansk velfoerdshistorie Bind II. Odense: Syddansk universitetsforlag.

Petersen, J. H. (2012). Dansk velfoerdshistorie Bind $I V$. Odense: Syddansk universitetsforlag. Petersen, J. H. (2013). Dansk velfoerdshistorie Bind $V$. Odense: Syddansk universitetsforlag.

Petersen, J. H. (2014). Dansk velfoerdshistorie Bind VI. Odense: Syddansk universitetsforlag. 
Rold Andersen, B. (1971). Grundprincipper i socialpolitikken. Albertslund: Socialpolitisk forening.

Socialministeriet, Beskæftigelsesministeriet og Finansministeriet (2007). Redegørelse om udviklingen på førtidspensionsområdet og det rummelige arbejdsmarked.

Stone, D. A. (1985). The disabled state. Basingstoke: Macmillan.

Streeck, W. \& Thelen, K. (2005). Introduction: Institutional change in advanced political economies. I Streeck, W. \& K. Thelen (red.), Beyond Continuity. Institutional change in advanced political economies (s. 1-39). New York: Oxford University Press.

Torfing, J. (2004). Det stille sporskifte i velfoerdsstaten: En diskursteoretisk beslutningsprocesanalyse. Århus: Aarhus Universitetsforlag.

\section{Noter}

1. Dansk velfærdshistorie har bidraget med nyttige udredninger (Petersen, 2011; Petersen, 2012; Petersen, 2013; Petersen, 2014). Endvidere findes en del fremstillinger i forskellige introduktioner til socialpolitik mv. Fremstillingen her er imidlertid også baseret på en retsdogmatisk analyse af gældende ret over tid.

2. Damgaard skitserer socialpolitikkens væsentligste sigte således: "Socialpolitikkens væsentligste sigte har været at sikre borgerne gode levevilkår i samfundet (Plovsing, 2000, s.26). Det har langt hen af vejen betydet at sikre borgerens økonomiske subsistens..." (Damgaard, 2003, s. 19).

3. Der er en række af eksempler på dette synspunkt f.eks. CASA, 2011; Hohnen, 2009

4. "De-commodification occurs when a service is rendered as a matter of right, and when a person can maintain a livelihood without reliance on the market." (Esping-Andersen, 1990, s. 21-22).

5. Hensynet til Sønderjydernes mere gunstige socialpolitiske ordning under Tysk herredømme pressede på for en tilsvarende dansk tryghedsordning (Petersen, 2011, s. 592-593).
6. Førtidspension erstatter invalidepension og enkepension samt nogle særordninger i folkepensionen.

7. Der kunne i helt ekstraordinære tilfælde tilkendes pension uden, at nedsættelsen af erhvervsevnen skyldes helbredsmæssige forhold.

8. "Da det må konstateres, at de eksisterende regler for beskrivelse, udvikling og vurdering af arbejdsevne i praksis ikke i tilstrækkeligt omfang har formået at understøtte udviklingsperspektivet, men i højere grad er blevet anvendt til at dokumentere manglende ressourcer, er det vigtigt, at den metodiske tilgang styrkes og udbygges sådan, at der kommer større fokus på udvikling af borgerens arbejdsevne i forhold til konkrete mål, der skal fastsættes i forbindelse med udformningen af jobplanen og rehabiliteringsplanen" (Lovforslag nr. 53, s.32).

9. En anekdote fra et jobcenter lyder således: Hvornår kan vi sige, at noget er åbenlyst formålsløst? Hvis vi eksempelvis har en mand, der har en depression og er uarbejdsdygtig som følge heraf. Det påvirker naturligvis hans overskud og hans arbejdsevne, og alle behandlingsmulighederne er tilsyneladende udtømt. En af følgevirkningerne af depressionen er bl.a. dårlig nattesøvn. Hvis vi nu forestiller os, at han fik en kugledyne. Kan vi udelukke, at denne kugledyne kunne bedre mandens nattesøvn? Hvis nu manden får en bedre nattesøvn, kan vi så udelukke, at han får mere energi og overskud, fordi han er mindre træt? Hvis manden får mere energi og overskud, kan vi så udelukke, at han vil kunne arbejde nogle timer i en virksomhedspraktik? Hvis manden kan arbejde nogle timer i en virksomhedspraktik, kan vi så udelukke, at han på sigt vil kunne blive helt eller delvist selvforsørgende, hvis han nu får det bedre psykisk af at være kommet i gang på arbejdsmarkedet igen? Så måske er afprøvning af en kugledyne ikke åbenlyst formålsløst, og dermed skal manden have et ressourceforløb og afprøve effekten heraf i en periode på 1-2 år. 
10. Tildelingskriteriet åbner også op for tildeling af førtidspension til personer på baggrund af andre forhold end helbredsmæssige.

11. Vejledningen om arbejdsevne er i dag ophævet, så der ikke længere er en officiel retlig definition af begrebet (Amby og Schaldemose, 2018)

12. Der er i principafgørelse $25-14$ eksempel på fleksjob ned til 40 minutter om ugen som ankestyrelsen har fundet i orden, hvis der fortsat er muligheder for udvikling af arbejdsevnen.

13. Klausen peger dog på, at en varig maksimal udviklet arbejdsevne omkring $1 / 3$ fortsat må være kriteriet (Klausen, 2017, s. 419).
14. Jf. Servicelovens §81: "Formålet med at yde støtte efter denne lov til voksne med nedsat fysisk eller psykisk funktionsevne eller med særlige sociale problemer er at sikre, at den enkelte får en sammenhængende og helhedsorienteret indsats, der modsvarer den enkeltes behov. Støtten skal ydes med det formål at styrke den enkeltes egne muligheder og eget ansvar for at udvikle sig og udnytte egne potentialer, i det omfang det er muligt for den enkelte. Desuden er formålet at medvirke til at sikre, at den enkelte kan fastholde sit aktuelle funktionsniveau, og at yde kompensation, omsorg og pleje."

15. Ikke mindst på sociale medier er dannet en del brugergrupper f.eks. jobcentrets ofre.

Finn Amby, Lektor, ph.d., Socialrådgiveruddannelsen VIA UC e-mail: fina@via.dk

Sisse Schaldemose, Adjunkt, Socialrådgiveruddannelsen VIA UC e-mail:scha@via.dk

Anders Bøggild Christensen, Lektor, ph.d., Socialrådgiveruddannelsen VIA UC e-mail:abc@via.dk 